\title{
Morphometric Analysis of Antegonial Notch and Posterior Ramus Flexure - its Clinical Significance
}

\author{
Rieshy. $V^{1}$ and Yuvaraj Babu $\mathrm{K}^{2 *}$ \\ ${ }^{1}$ Saveetha Dental College and Hospitals, Saveetha Institute of Medical \\ and Technical Sciences, Saveetha University, Chennai -600077, India \\ ${ }^{2}$ Assistant professor, Department of Anatomy, Saveetha Dental College and Hospitals, \\ Saveetha Institute of Medical and Technical Sciences, Saveetha University, Chennai -600077, India
}

\begin{abstract}
Mandible bone is the largest and the strongest bone present in the human face. It is a lower jaw bone that is present beneath the maxilla. It holds the lower teeth. Mandible bone is formed from the first pharyngeal arch during its intrauterine life. This bone provides maximum attachment of muscle of mastication and facial expression. The body of the mandible has 2 borders. Ramus of the mandible is a prominent projecting back parts of the horse shoe shaped lower jaw bone. The antegonial notch is present in the inferior border of the mandible at the junction between the ramus and body of the mandible. At the level of the molar occlusal surface there is distinct angulation of the ramus of mandible in its posterior border. This type of angulation on the posterior border is known as posterior ramus flexure. The aim of this research is to morphologically analyse the antegonial notch and posterior ramus flexure and its clinical importance. Fifty-one dry adult human mandibles of unknown sex collected from the Department of Anatomy of Saveetha Dental College. For each mandible, detailed measurements of Antegonial notch and Posterior ramus flexure were taken. There is a presence of 3 types of Antegonial notch and 3 types of Posterior ramus flexure that were discovered and measured separately in fifty-one dry adult human mandibles of unknown sex. The shape, size and the position of the antegonial notch and posterior ramus flexure can be used as one of the tools as an indicator for Sexual Dimorphism. Other researchers have found many indicators for sexual dimorphism as a tool to identify the sex, age, race, etc. There is various evidence that represent and identifies the difference between sex, age and gender and many anatomical features supports it.
\end{abstract}

KEY WORDS: ANTIGONIAL NOTCH, POSTERIOR RAMUS FLEXURE, SEXUAL DIMORPHISM, MANDIBLE MEASUREMENTS.

\section{INTRODUCTION}

Mandible bone is the largest and the strongest bone present in the human face. It is a lower jaw bone that is present beneath the maxilla. It holds the lower teeth.

\section{ARTICLE INFORMATION}

*Corresponding Author: yuvarajbabu@saveetha.com Received 25th June 2020 Accepted after revision 5th August 2020 Print ISSN: 0974-6455 Online ISSN: 2321-4007 CODEN: BBRCBA

Thomson Reuters ISI Web of Science Clarivate Analytics USA and Crossref Indexed Journal

\section{Clarivate
Analytics}

NAAS Journal Score 2020 (4.31) SJIF: 2020 (7.728)

A Society of Science and Nature Publication,

Bhopal India 2020. All rights reserved.

Online Contents Available at: http//www.bbrc.in/

Doi: $h t t p: / / d x$.doi.org/10.21786/bbrc/13.7/92
Mandible bone is formed from the first pharyngeal arch during its intrauterine life. This bone provides maximum attachment to the muscle of mastication (Sella-Tunis et al., 2018). Ramus of the mandible is a prominent projecting back parts of the lower jaw bone (Raj and Ramesh, 2013). It has four sides, two surfaces, four borders and two processes. The two important processes are the coronoid and the condyloid process (Isaac and Holla, 2001). These two processes are separated by the mandibular notch. It is a deep semilunar depression. The mandibular ramus is almost vertical in adulthood but more oblique in old age (Vignesh, Babu and Mohanraj, 2018). The anterior part of the ramus can be used as the donor site for reconstruction of small bone defects in 
the Oral and maxillofacial region (Radlanski, Renz and Klarkowski, 2003). The mandible has two foramen, the mandibular and mental foramen. Males generally have a stronger and larger mandible than females (Loth and Henneberg, 2001).

When describing the mandible bone, various researchers have studied the importance of various anatomical structures that are present in the mandibles. The relationship of lingula to the inferior alveolar nerve, which enters the mandibular foramen and supplies the structures of the lower jaw is of clinical significance to the dental surgeons (Nirmale et al., 2012). The spatial relationship of the mandibular canal to the posterior teeth in dried human mandible (Denio, Torabinejad and Bakland, 1992). The remodeling process of the condylar processes a clinical sense that can be looked upon as restitutions in children and adjusting or functional in adults (Hollender and Lindahl, 1974). Position of the mandibular foramen is responsible for an occasional failure of block to the inferior alveolar nerve (Nicholson, 1985). The mental foramen is an important landmark when considering placing implants in the foraminal region (Greenstein and Tarnow, 2006).

Antegonial notch and Posterior ramus flexure are such anatomical structures that are present in the mandibles. The antegonial notch is located in the inferior border of the mandible at the junction between the ramus and body of the mandible (Kolodziej et al., 2002). The actions of elevators and depressors muscles that helps in the mastication process during growth causes the distinctive antegonial notching in the mandible (Madhavan, Dhanraj and Jain, 2018) (Singer, Mamandras and Hunter, 1987). At the level of the molar occlusal surface there is distinct angulation of the ramus of mandible in its posterior border. This type of angulation on the posterior border is known as posterior ramus flexure (Hill, 2000). With a rich case bank established over 3 decades we have been able to publish extensively in our domain (Abdul Wahab et al., 2017; Eapen, Baig and Avinash, 2017; Patil et al., 2017; Jain and Nazar, 2018; J et al., 2018; Marimuthu et al., 2018; Wahab et al., 2018; Abhinav et al., 2019; Ramadorai, Ravi and Narayanan, 2019; Senthil Kumar et al., 2019; Sweta, Abhinav and Ramesh, 2019). Based on this inspiration the aim of this study was to morphometrically analyse the antegonial notch and posterior ramus flexure of mandible and its clinical importance.

\section{MATERIAL AND METHODS}

Fifty-one dry adult human mandibles of unknown sex collected from the Department of Anatomy of Saveetha Dental College. For each mandible, detailed measurements of Antegonial notch and Posterior ramus flexure were taken. The sides are named separately. Due to the formation of the triangular shape that these sides form, they were classified under 3 different categories.

A) Three types of Antegonial Notch

Type $1 \rightarrow$ Asymmetrical posterior notch
Type $2 \rightarrow$ Symmetrical notch

Type $3 \rightarrow$ Asymmetrical anterior notch

B) Three types of Posterior Ramus Flexure

Type $1 \rightarrow$ Posterior ramus flexure is flexed at the level of the occlusal surface of the molars.

Type $2 \rightarrow$ Posterior ramus flexure is straight juvenile shape.

Type $3 \rightarrow$ Posterior ramus flexure is flexed above the occlusal level near the neck of the condyle.

All measurements and the frequency of occurring were tabulated and statistically analyzed.

\section{RESULTS AND DISCUSSION}

Both the Antigonial notch and posterior ramus flexure is measured and the frequency of occurring is made into a tabular column.

\section{A) For Antegonial Notch}

Table 1. Frequency of individual types of Antigonial notch in mandible observed on right and left side

\begin{tabular}{|c|c|c|}
\hline & LEFT & RIGHT \\
\hline TYPE 1 & $29(56.86 \%)$ & $24(47.05 \%)$ \\
\hline TYPE 2 & $18(35.29 \%)$ & $21(41.17 \%)$ \\
\hline TYPE 3 & $4(7.84 \%)$ & $6(11.76 \%)$ \\
\hline TOTAL & $51(100 \%)$ & $51(100 \%)$ \\
\hline
\end{tabular}

B) For Posterior Ramus Flexure

Table 2. Frequency of individual types of Posterior ramus flexure in mandible observed on right and left side

\begin{tabular}{|l|c|c|}
\hline & LEFT & RIGHT \\
\hline TYPE 1 & $27(52.94 \%)$ & $25(49.01 \%)$ \\
\hline TYPE 2 & $5(9.80 \%)$ & $8(15.68 \%)$ \\
\hline TYPE 3 & $19(37.25 \%)$ & $18(35.29 \%)$ \\
\hline TOTAL & $51(100 \%)$ & $51(100 \%)$ \\
\hline
\end{tabular}

The antegonial notch is present in the inferior border of the mandible at the junction between the ramus and body of the mandible, immediately anterior to its angle knowledge about anatomy of the antegonial notch may be useful for surgeons during reconstructive and plastic surgery procedures on the body of the mandible. In one of the articles, titled as Typology of the antegonial notch in the human mandible, the authors viewed 251 human caucasian, european mandible, where Type - 3 has the highest frequency whereas Type - 1 has the lowest frequency and Type - 2 occurred more or less equal to Type - 3 (Porwolik et al., 2015). In our study we found more of Type 1 type. 
At the level of the molar occlusal surface there is distinct angulation of the ramus of mandible in its posterior border (Balci, Yavuz and Cagdir, 2005). This type of angulation on the posterior border is known as posterior ramus flexure. This flexure appears as a male developmental trait because it is only manifest consistently after adolescence. In females the posterior border of the ramus retained a straight shape (Loth and Henneberg, 1996). In our observation most of the posterior ramus flexure occurs at the level of occlusal surface (Type 1) followed by flexure near the neck of mandible (Type 3) and straight juvenile type was found the least (Type 3).

Other researchers have found many indicators for sexual dimorphism as a tool to identify the sex, age, race, etc (Kumar and Babu, 2016). There is various evidence that represent and identifies the difference between sex, age and gender and many anatomical features supports it (G, Gowri S R and J, 2013). Therefore, this research proves that the shape, size and the position of the antegonial notch and posterior ramus flexure can be used to classify the mandible into 3 types.

\section{CONCLUSIONS}

It can be analyzed that both the Antigonial notch and the posterior ramus flexure can be used to classify the mandible further study using sexed mandible is recommended to use these features as an indicator for the sexual dimorphism. By viewing the shape and size of the human mandible parts, i.e. the curvature of the antigonial notch and the distinct angulation, various parameters like sex, age, race, etc can be estimated.

\section{ACKNOWLEDGEMENTS}

We acknowledge Department of Anatomy for allowing us to use bones from their collection for this study.

Conflict of Interest: The author declares that there is no conflict of interest in the present study.

\section{REFERENCES}

Abdul Wahab, P. U. et al. (2017) 'Risk Factors for Postoperative Infection Following Single Piece Osteotomy', Journal of maxillofacial and oral surgery, 16(3), pp. 328-332.

Abhinav, R. P. et al. (2019) 'The Patterns and Etiology of Maxillofacial Trauma in South India', Annals of maxillofacial surgery, 9(1), pp. 114-117.

Balci, Y., Yavuz, M. F. and Cagdir, S. (2005) 'Predictive accuracy of sexing the mandible by ramus flexure', Homo: internationale Zeitschrift fur die vergleichende Forschung am Menschen. Elsevier, 55(3), pp. 229237.

Denio, D., Torabinejad, M. and Bakland, L. K. (1992) 'Anatomical relationship of the mandibular canal to its surrounding structures in mature mandibles', Journal of Endodontics, pp. 161-165. doi: 10.1016/s0099-
2399(06)81411-1.

Eapen, B. V., Baig, M. F. and Avinash, S. (2017) 'An Assessment of the Incidence of Prolonged Postoperative Bleeding After Dental Extraction Among Patients on Uninterrupted Low Dose Aspirin Therapy and to Evaluate the Need to Stop Such Medication Prior to Dental Extractions', Journal of maxillofacial and oral surgery, 16(1), pp. 48-52.

Greenstein, G. and Tarnow, D. (2006) 'The Mental Foramen and Nerve: Clinical and Anatomical Factors Related to Dental Implant Placement: A Literature Review', Journal of Periodontology, pp. 1933-1943. doi: 10.1902/jop.2006.060197.

G, V., Gowri S R, M. and J, A. (2013) 'Sex determination of human mandible using metrical parameters', Journal of clinical and diagnostic research: JCDR. ncbi.nlm.nih. gov, 7(12), pp. 2671-2673.

Hill, C. A. (2000) 'Evaluating mandibular ramus flexure as a morphological indicator of sex', American Journal of Physical Anthropology: The Official Publication of the American Association of Physical Anthropologists. Wiley Online Library, 111(4), pp. 573-577.

Hollender, L. and Lindahl, L. (1974) 'Radiographic study of articular remodeling in the temporomandibular joint after condylar fractures', European Journal of Oral Sciences, pp. 462-465. doi: 10.1111/j.1600-0722.1974. tb00402.x.

Isaac, B. and Holla, S. J. (2001) 'Variations in the shape of the coronoid process in the adult human mandible', Journal of the Anatomical Society of India. pdfs. semanticscholar.org, 50(2), pp. 137-139.

Jain, M. and Nazar, N. (2018) 'Comparative Evaluation of the Efficacy of Intraligamentary and Supraperiosteal Injections in the Extraction of Maxillary Teeth: A Randomized Controlled Clinical Trial', The journal of contemporary dental practice, 19(9), pp. 1117-1121.

J, P. C. et al. (2018) 'Prevalence and measurement of anterior loop of the mandibular canal using CBCT: A cross sectional study', Clinical implant dentistry and related research, 20(4), pp. 531-534.

Kolodziej, R. P. et al. (2002) 'Evaluation of antegonial notch depth for growth prediction', American journal of orthodontics and dentofacial orthopedics: official publication of the American Association of Orthodontists, its constituent societies, and the American Board of Orthodontics. Elsevier, 121(4), pp. 357-363.

Kumar, J. S. and Babu, Y. K. (2016) 'Sex determination using human mandible', Research journal of pharmaceutical, biological and chemical sciences. Journal of Pharmaceutical Sciences and Research, 8(6), p. 487.

Loth, S. R. and Henneberg, M. (1996) 'Mandibular ramus flexure: A new morphologic indicator of sexual dimorphism in the human skeleton', American Journal of Physical Anthropology, pp. 473-485. doi: 3.0.co;2x">10.1002/(sici) 1096-8644(199603)99:3<473::aidajpa8>3.0.co;2-x. 
Loth, S. R. and Henneberg, M. (2001) 'Sexually dimorphic mandibular morphology in the first few years of life', American journal of physical anthropology. Wiley Online Library, 115(2), pp. 179-186.

Madhavan, S., Dhanraj, M. and Jain, A. R. (2018) 'Methods of recording mandibular movements-A review', Drug Invent. Today. researchgate.net, 10, p. 1259.

Marimuthu, M. et al. (2018) 'Canonical Wnt pathway gene expression and their clinical correlation in oral squamous cell carcinoma', Indian journal of dental research: official publication of Indian Society for Dental Research, 29(3), pp. 291-297.

Nicholson, M. L. (1985) 'A study of the position of the mandibular foramen in the adult human mandible', The Anatomical Record, pp. 110-112. doi: 10.1002/ ar.1092120116.

Nirmale, V. K. et al. (2012) 'Morphological features of human mandible', Int J Recent Trends Sci Aechnol. researchgate.net, 3, pp. 33-43.

Patil, S. B. et al. (2017) 'Comparison of Extended Nasolabial Flap Versus Buccal Fat Pad Graft in the Surgical Management of Oral Submucous Fibrosis: A Prospective Pilot Study', Journal of maxillofacial and oral surgery, 16(3), pp. 312-321.

Porwolik, M. et al. (2015) 'Typology of the antegonial notch in the human mandible', Folia Morphologica, pp. 365-371. doi: 10.5603/fm.2015.0055.

Radlanski, R. J., Renz, H. and Klarkowski, M. C. (2003) 'Prenatal development of the human mandible', Anatomy and embryology. Springer, 207(3), pp. 221232.

Raj, J. D. and Ramesh, S. (2013) 'Sexual dimorphism in mandibular ramus of South Indian population', Antrocom Online J Anthropol. pdfs.semanticscholar. org, 9, pp. 253-258.

Ramadorai, A., Ravi, P. and Narayanan, V. (2019) 'Rhinocerebral Mucormycosis: A Prospective Analysis of an Effective Treatment Protocol', Annals of maxillofacial surgery, 9(1), pp. 192-196.

Sella-Tunis, T. et al. (2018) 'Human mandibular shape is associated with masticatory muscle force', Scientific reports. nature.com, 8(1), p. 6042.

Senthil Kumar, M. S. et al. (2019) 'Inflammatory pseudotumour of the maxillary sinus: clinicopathological report', Oral Surgery, 12(3), pp. 255-259.

Singer, C. P., Mamandras, A. H. and Hunter, W. S. (1987) 'The depth of the mandibular antegonial notch as an indicator of mandibular growth potential', American journal of orthodontics and dentofacial orthopedics: official publication of the American Association of Orthodontists, its constituent societies, and the American Board of Orthodontics. Elsevier, 91(2), pp. 117-124.

Sweta, V. R., Abhinav, R. P. and Ramesh, A. (2019) 'Role of Virtual Reality in Pain Perception of Patients Following the Administration of Local Anesthesia', Annals of maxillofacial surgery, 9(1), pp. 110-113.

Vignesh, P., Babu, K. Y. and Mohanraj, K. G. (2018) 'Morphometric analysis of gonial angle and mandibular ramus measurement as predictors of sex and age in dry human mandibles', Drug Invention Today. search.ebscohost.com, 10(10). Available at: https://bit. ly/319bpDo.

Wahab, P. U. A. et al. (2018) 'Scalpel Versus Diathermy in Wound Healing After Mucosal Incisions: A SplitMouth Study', Journal of oral and maxillofacial surgery: official journal of the American Association of Oral and Maxillofacial Surgeons, 76(6), pp. 1160-1164. 